\title{
Foreign Policy and National Interest: Realism and Its Critiques
}

\author{
Munafrizal Manan
}

Universitas Al-Azhar Indonesia

\begin{abstract}
Realism stated that conflict or even war among countries are acceptable in order to achieve national interest. Such a view has become the mainstream in international relations (IR) both theoretically and practically. But it does not mean that realist views are the best approach to discuss foreign policy and national interest. Liberalism and global humanism can be used as alternative approaches to discuss it. From the perspective of liberalism and global humanism, foreign policy is not only reflecting national interest, but also dealing with human and global interest. By focussing on the issues of economic globalization, democracy, human rights, and environment, the approaches of liberalism and global humanism show that these issues have now become a part of foreign policy and national interest of countries. It means that if it comes to human and global interests, then countries choose to cooperate globally rather than to involve in conflict or war.
\end{abstract}

Keywords: Foreign Policy, National Interest, Realism, Liberalism, Humanism Global.

Realisme memandang bahwa konflik dan bahkan perang dapat diterima dalam rangka mencapai kepentingan nasional. Pandangan seperti ini telah menjadi arus utama dalam hubungan internasional baik secara teoretis maupun praktis. Namun ini tidak berarti pandangan kaum realis adalah pendekatan terbaik untuk membahas kebijakan luar negeri dan kepentingan nasional. Liberalisme dan humanisme global dapat digunakan sebagai pendekatan alternatif untuk mendiskusikan hal tersebut. Dari perspektif liberalisme dan humanisme global, kebijakan luar negeri tidak hanya merefleksikan kepentingan nasional, tetapi juga berkaitan dengan kepentingan kemanusiaan dan global. Dengan fokus pada isu-isu globalisasi ekonomi, demokrasi, hak asasi manusia, dan lingkungan, pendekatan liberalisme dan humanisme global membuktikan bahwa isu-isu ini telah menjadi bagian dari kebijakan luar negeri dan kepentingan nasional negaranegara. Artinya, jika itu berhubung-an dengan kepentingan kemanusiaan dan global, maka negara-negara memilih untuk bekerja sama secara global daripada terlibat dalam konflik atau perang.

Kata-Kata Kunci: kebijakan luar negeri, kepentingan nasional, realisme, liberalisme, humanisme global 
It is often argued that foreign policy of a country reflects its national interest. Foreign policy is likely formulated in accordance with national interest (Jackson and Sørensen 2003, 68). This is why there is a relationship between foreign policy and national interest. Such a view is dominant in the study of IR and demonstrates the way realists analyse international politics (Sutch and Elias 2007, 54 \& 117). Traditional view of foreign policy is therefore often associated with realist perspective (Webber and Smith 2002, 11-15).

The view above is still valid to some extent. National interest remains the main reason for countries to involve in international relations and have international cooperation with other countries. However, the robustness of realist arguments is problematic as criticized by its contenders such as liberalism and global humanism. The aim of the article is to examine the views of realism on foreign policy and national interest by referring to liberalism and global humanism. The central issues of liberalism here are economic globalization and democracy. For liberalism, economy and democracy are necessary for global peace. Global humanism is used "to redefine security within and between states: human development, human security, and common security" (Gurtov 2007, 101-2). The central issues of global humanism here are human rights and environment.

This article is divided into three sections. The first section presents the view of realism. The next section provides the arguments of liberalism by focusing on the issues of economic globalization and democracy. The last section provides the view of global humanism on world affairs and then discusses the issues of human rights and environment.

\section{Realist Approach}

Realism is the dominant mainstream theory in the field of IR (Dunne and Schmidt 2001, 141; Heywood 2011, 53). However, realism is contended by other theories such as liberalism, constructivism, and the English School. To some extent, the practice of international politics today is still in accordance with the principles of realism. State actors, power competition, self-help strategy, national interest, the world disorder, and the balance of power remain important aspects in international politics. Realism is therefore central to international politics both theoretically and practically. As Dunne and Schmidt note, "[f]rom 1939 to the present, leading theorists and policymakers have continued to view the world through realist lenses" (Dunne and Schmidt 2005, 162). 
The emergence of realism is to criticize idealists who "focused much of their attention on understanding the cause of war so as to find a remedy for its existence" (Dunne and Schmidt 2005, 162). Idealists argued that every state prefer to live in coexistence and peace as well as to cooperate with others in order to pursue their common interests. For realists, such a view is no more than a wishful thinking. The prominent realists such as Hans J Morgenthau in his seminal book named Politics Among Nations (2006) tried to explain international politics on the ground the so-called the objective laws or law-like regularities, not moral precepts or abstract idea.

Realists argue that states are always involved in power competition as a result of the will to survive and dominate other countries. Thus, the most important thing for states is power. International politics is about power, and every state struggles to gain power (Morgenthau 2006). Power can be defined in terms of economic, military, and cultural power; they will change over time (Burchill 2005, 36). This motivates states to become the great power which allow them to be supreme than other states. With the great power states can pursue effectively their national interests. However, it produces competition and conflict among states, and possibly leads to international anarchy or the world disorder. This is why states have to pursue the balance of power in order to preclude the domination of other states (Sutch and Elias 2007, 54-56). The balance of power can only be achieved through a bipolar world system like the era of the Cold War (Sutch and Elias 2007, 57-58).

Realists emphasize human nature in international politics which means that human nature causes states to act in certain ways and is inherently self-interested which gives us a tendency to conflict (Sutch and Elias 2007, 46 \& 48). Neo-realists, often mentioned structural realists, offer a modified view of realism. The influential neo-realists like Kenneth $\mathrm{N}$. Waltz in his influential book entitled Theory of International Politics (1979) argues that what is important for states is not power, but rather security. Thus states are not power maximizers, but rather security maximizers which mean that the ultimate goal of states is to pursue security rather than power. Moreover, Waltz argues that competition and conflict among states are not simply the result of human nature, but coming from the absence of supreme authority beyond states and the problem of power distribution among states. Contrary to realists, Waltz emphasizes the importance of international system in international politics which has been ignored by realists.

However, there is a consensus among realists with regard to the three core elements of realism: statism, survival, and self-help (Dunne and Schmidt 2005, 163). There is also a similarity among them in viewing foreign policy and national interest (Goldstein and Pevehouse 2008, 60 
\& 75). Realists agree that foreign policy is only to serve national interest in the realm of international politics. Realists see foreign policy and national interest in terms of the struggle for power and the survival of state (Jackson and Sørensen 2003, 82). Consequently, the relationship between countries tends to be adversarial rather than cooperative. Countries will be involved in international conflict and they will look for cooperation only to make an alliance in order to face common enemies.

Realists believe that international politics is anarchical as a result of the absence of the world government (Jackson and Sørensen 2003, 68; Dunne and Schmidt 2001, 143) which is assumed more supreme than sovereign states. As a consequence, states are living in a hostile and threatening environment which potentially leads to war. This explains why the primary national interest of nation-states is the pursuit of national security, usually defined as physical survival and territorial integrity (Burchill 2005, 47). This encourages states to strengthen its military force in order to survive and defend themselves from external military attack of other states. For this reason, the military preparations of one state are likely to be matched by neighbouring states (Dunne and Schmidt 2001, 153). This arms race brings states into the preparation for war although they do not know exactly when it will occur. For realist, the core national interest of all states must be survival because other interests such as economic, environmental, and humanitarian cannot be achieved if the existence of states is jeopardized (Dunne and Schmidt 2005, 164). The survival is a precondition for attaining all other goals (Dunne and Schmidt 2005, 174).

Realism in part is still relevant today, although it is far from being perfect. States remain the principal actors in the realm of international politics even though their role has now been undermined by other international actors such as international organizations, multinational corporations, and transnational actors. Nation-state remains a preferred form of political community and no other institution than nation-state can still command the political allegiances of its citizens or adjudicate in disputes between them and has the exclusive authority to bind the whole community to international law (Burchill 2005, 55). The survivability of state is essential and therefore military force is important to protect national security or to counter unpredictable external military attack.

Since the views of realism on foreign policy and national interest focuses on the interest of state, it can be argued that realism seems to ignore the importance of global interest or human interest. For realists, sovereign states remain the major actors in international politics. The behaviour of states is motivated by their self-interest rather than the interest of human beings. Realists also tend to focus on international conflict and ignore the possibility of international cooperation. In fact, both 
international conflict and cooperation are inherent parts of international system.

\section{Liberal Approach}

In contrast to realism, liberalism has an optimistic view of foreign policy and national interest. Liberal scholars have great faith in human reason and they are convinced that rational principles can be applied to international affairs (Jackson and Sørensen 2003, 106). They do not deny that the characters of individuals are self-interested and competitive. Yet they also believe that individuals share many interests and can thus engage in collaborative and cooperative social action, domestically as well as internationally, which results in greater benefits for everybody at home and abroad (Jackson and Sørensen 2003, 107). According to liberal scholars, the prospect for co-operation, even in an anarchical world, are greater than neo-realists would have us believe (Burchill 2005, 121).

In the view of liberalism, national interests should focus on the pursuit of peace-a harmony between nations (Burchill 2005, 125). Liberalism rejects realism that views international politics in the lens of conflict, suspicion and competition between sovereign states. For liberalism, "[t]he laws of nature dictated harmony and co-operation between peoples" (Burchill 2005, 112). Liberals contend realists who believe that war is inevitably inherent to the realm of international politics. For them, "[w]ar is therefore both unnatural and irrational, an artificial contrivance and not a product of some peculiarity of human nature", and therefore they "have a belief in progress and the perfectibility of the human condition" (Burchill 2005, 112). In the view of liberalism, "[w]ars provided governments with excuse to raise taxes, expand their bureaucratic apparatus and thus increase their control over their citizens" (Burchill 2005, 112).

To treat the disease of war, liberalism prescribe "the twin medicines of democracy and free trade" (Burchill 2005, 112-113, original emphasis). Liberalism argues that "[d]emocratic processes and institutions would break the power of the ruling elites, and curb their propensity for violence" (Burchill 2005, 113). Liberals believe that the spread of democracy across the globe is required to pacify international politics (Burchill 2005, 116). Similarly, free trade and commerce would overcome the artificial barriers erected between individuals and unite them everywhere into one human community (Burchill 2005, 113). In addition, "[f]ree trade would expand the range of contacts and levels of understanding between the peoples of the world and encourage international friendship, cosmopolitan thinking and understanding" (Burchill 2005, 118). In this light, liberals advocate the importance of 
economic liberalism by "focus[ing] on the promotion of market relations as the optimal form of economic organisation" as well as political liberalism "regard[ing] the spread of liberal-democracy as an antidote to conflict in the international system" (Burchill 2005, 104-105). Thus economic globalization and the democratic peace theory are the twin medicines offered by liberalism for the world.

Economic globalization refers to economic activities across the globe which leads to the interconnectedness and interdependence among countries (Steger 2003, 37; Yeung 2002, 287). Robert Jackson and Georg Sørensen argue that "[t]rue economic globalisation involves a qualitative shift towards a world economy that is no longer based on autonomous national economies; rather, it is based on a consolidated global marketplace for production, distribution, and consumption" (Jackson and Sørensen 2003, 213). According to Jan Aart Scholte (2001, 520-525), there are three contrasting ways in economic globalization: the crossing of borders, the opening of borders, and the transcendence of borders. The first focuses on "increased cross-border movements between countries of people, goods, money, investments, messages, and ideas" (Scholte 2001, 520). Globalization is seen as a synonymous with internationalization. According to the second, contemporary economic globalization is "as part of the long term evolution towards a global society" (Scholte 2001, 522). In addition, globalization entails not an extension of internationalization, but the progressive removal of official restrictions on transfer of resources between countries (Scholte 2001, 522). Economic globalization means that global replaces international of economic activities by opening the borders, and hence economic globalization is viewed as a synonymous with liberalization. The third highlights the process whereby social relations acquire relatively distanceless and borderless qualities (Scholte 2001, 525). It emphasizes the importance of geographical interpretations in economic globalization.

The phenomenon of the globalization of the world economy suggests that the arguments of realists need to be evaluated. Economic globalization challenges the argument of realism that nation-states are the principal actors in international arena. In economic globalization, the roles of multinational and transnational corporations in economic activities are pivotal and to some extent have taken over the role of nations-states (Mansbach and Rafferty 2008, 539). Globalization pressures nation-states to open cross-border activities which resulted in nation-states are no longer able to control on their own-such as global economic transactions and environmental problems (Jackson and Sørensen 2003, 214).

Economic globalization also contends the view of realism on national interest. Economic global-ization generates an interdependent relationship between nation-states and therefore "national interests as 
they are conventionally understood [by realists] would gradually give way to global interests" (Burchill 2005, 120). In interdependent relationship, nation-states prefer to be cooperative rather than conflicting and thinking in terms of mutual benefits rather than a narrow national interest (Burchill 2005, 120-121). In the words of Jackson and Sørensen, "[u]nder complex interdependence, transnational actors are increasingly important, military force is a less useful instrument, and welfare-not security-is becoming the primary goal and concern of states" (Jackson and Sørensen 2003, 116). Liberalism believe that "economic interdependency is pacifying international relations" (Burchill 2005, 123) and make the world "more cooperative international relations" (Jackson and Sørensen 2003, 116).

The next issue of liberalism discussed here is democracy. The discussion of democracy is dealing with the-so called the democratic peace theory, which is "probably the most powerful liberal contribution to the debate on the cause of war and peace" (Rosato 2003, 585). The democratic peace theory argues that it never or at least rarely happens that democratic countries get involved in war against each other. It is also argued that "democracies have almost never fought each other" (Russett 1993, 4). Liberals believes that the power of liberal-democracy for international peace is by spreading it across the world. The more democratic is the more peaceful. Democracy is viewed as a selfconstraint mechanism for war. However, it does not mean that "democracies never go to war; democracies have gone to war as often as have non-democracies" (Jackson and Sørensen 2003, 120). But the proponents of the democratic peace theory believe that "democracies do not fight each other" (Jackson and Sørensen 2003, 120).

The democratic peace theory is rooted in the idea of Immanuel Kant through his influential essay entitled Perpetual Peace: A Philosophical Sketch written in 1795. Kant provided a philosophical justification for the democratic peace theory. Kant "posited that a republican form of government, exemplifying the rule of law, provides a feasible basis for states to overcome structural anarchy and to secure peaceful relations among themselves" (cited in Chan 1997, 60). A number of studies tried to confirm the validity of the democratic peace theory. Dean Babst noted that "no wars have been fought between independent nations with elective governments between 1789 and 1941" (Babst 1972, 55 cited in Chan 1997, 60). Melvin Small and David Singer (1976) also have the same finding in their study which found that "democracies participated in fewer wars than nondemocracies from 1815 through 1965" (cited in Chan 1997, 61). Such conclusions are also supported by Zeev Maoz and Nasrin Abdolali who found that "[b]ased on their analysis of data spanning 150 years, democracies "never" fight each other" (Maoz and Abdolali cited in Gowa 1999, 5). A number of studies conducted in the 
late 1980 and the early 1990 s have come to "an apparent consensus: although democracies are not generally less warlike than nondemocracies (the so-called monadic hypothesis), they rarely (if ever) fight each other (the dyadic hypothesis)" (Chan 1997, 61). These findings encourage liberal scholars and policymakers to be optimistic with a longterm world peace.

According to Jackson and Sørensen $(2003,121)$, there are three elements supporting the democratic peace theory. First is dealing with "the existence of domestic political cultures based on peaceful conflict resolution". In this sense, "[d]emocracies encourages peaceful international relations because democratic governments are controlled by their citizens, who will not advocate or support wars with other democracies". Second is relating to the relationship between democracies and common moral values. In this context, "[p]eaceful ways of solving domestic conflict are seen as morally superior to violent behaviour, and this attitude is transferred to international relations between democracies". Third, "peace between democracies is strengthened through economic cooperation and interdependence" in order to build a more close relation.

The arguments of liberalism above show that foreign policy is not merely dealing with conflict and war as realism argues, but also dealing with cooperation and peace. The realist view on foreign policy is therefore not adequate to explain the global phenomenon of economy and democracy as the ingredients for global peace. Similar to liberalism, global humanism also criticizes the realist view on foreign policy. Whereas liberalism emphasizes the importance of cooperation and peace in foreign policy, global humanism highlights the urgency of global interest or human interest. In the following paragraphs, global humanism shows that foreign policy of states is not only about national interest, but also about global interest or human interest.

\section{Global Humanism Approach}

For realists, the relationship among countries is based on self-interest (who gets what, when and how) and quid pro quo (something for something or what for what). In fact, foreign policy is not only motivated by national interest, but also by global interest. As global humanists argue, there has been global attention to global crisis which is approached by human interest point of view. Countries are united by shared values and interests in terms of humanity, liberty, welfare, and the future of the globe and human beings. They work together to pursue these global values and interests regardless of the differences of vested interests. Nowadays, there is a broad awareness of common global 
interests. As Mel Gurtov notes, the "[global] events of the 1980s and 1990 s have one thing in common: They reflect the increasingly complex and transnational character of world politics" (Gurtov 2007, 7). As a consequence, it is "difficult to escape the influence of the broader international arena" (Hocking and Smith 1995, 2). Global communities believe that "we live in a global risk which has to confront transboundary dangers" and it is "often beyond the control of a single state or a group of states" (Doods 2000, 47).

Global humanism tries to offer an alternative view to explain international politics beyond realist approach. In the view of global humanism, the global agenda today has become "larger, more diverse, and more ominous" and therefore it requires "additional tools to analyze it" which is based on an interdisciplinary approach (Gurtov 2007, 7-8). Realist approach is not adequate to explain the complexity of the world since "the framework of competing national interest cannot cope with planed-wide problems" (Gurtov 2007, 8). In contrast to realism, "global humanism openly acknowledges the principal values and norms that determine its orientation" such as peace, social and economic justice, political justice, ecological balance, and human governance (Gurtov 2007, 98). Global humanism believes that "human beings are by nature good hearted, peaceful, sharing, and infinitely creative" (Gurtov 2007, 99). Global humanism therefore rejects "the inevitability of war, permanent enemies, and permanent crisis" (Gurtov 2007, 101) as repeatedly echoed by realists.

The core element of global humanism is "the primacy of the human interest above any other-state, ideological, economic, or bureaucratic" (Gurtov 2007, 98). Global humanism "looks at the world from the standpoint of the needs and interests of the planet" which is hoped can be applied universally (Gurtov 2007, 8). Global humanism argues that "global problems such as poverty, hunger, environmental destruction, terrorism, and the arms race need to be solved by analyzing their structural roots, without regard to political or economic character of states" (Gurtov 2007, 100). Global humanism pays a close attention to equity, social justice, and environmental considerations of the international politics realm. In discussing the issues of global humanism, the article is limited to the issues of human rights and environment because these issues have appeared more frequently and seriously on the foreign policy agenda. Besides, humanitarian and environmental problems have in fact encouraged the attention of humanists across the globe.

A more serious attention to the protection and enforcement of human rights has been devoted since the late 1940s onwards. The atrocities of the Second World War have encouraged international communities to 
formulate international human rights regulations and created international human rights institutions. The establishment of the United Nations in 1945 in order to preserve international peace and to protect human rights universally as well as the adoption of the Universal Declaration of Human Rights in 1948 demonstrate the importance of human rights as a global agenda without being restricted by a narrow consideration of national interests. At the present time, there are a number of international human rights documents such as the International Convention on the Elimination of All Forms of Racial Discrimination (1965), the International Covenant on Civil and Political Rights (1966), the International Covenant on Economic, Social, and Cultural Rights (1966), and the International Convention on the Elimination of Discrimination against Women (1979). Besides, there are also international and regional human rights courts like the International Criminal Court and the European Court of Human Rights.

The recent decades have witnessed the importance of human rights in international relations. According to David P. Forsythe, "[h]uman rights was widely seen as a useful means to help achieve human dignity in contemporary international relations" (Forsythe 2006, 25). For Peter R. Baehr and Monique Castermans-Holleman, human rights are now "an essential part of international politics" and "[t]hey serve either as a goal or as an instrument of foreign policy" (Baehr and Castermans-Holleman 2004, 130). Foreign policy is used by policy makers "to influence another state or group of states so that they may improve the respect of human rights" (Baehr and Castermans-Holleman 2004, 2).

Nowadays, human rights is not only a domestic issue, but also a global issue. Moreover, "human rights was no longer a matter necessarily or always within state domestic jurisdiction" (Forsythe 2006, 4). State is not allowed to violate its citizen human rights rampantly. State has a duty to respect and enforce human rights. Today, the violation of human rights in a country will attract the attention of other states and global communities. It can be a reason for a humanitarian intervention by global communities in order to stop the violation and bring the perpetrators to the court. In relation to this, the missions of the United Nations Security Council have played a pivotal role, for examples, in the former Yugoslavia (1992-1993), Somalia (1992), Rwanda (1994), and Haiti (1994), despite there is also criticism regarding its role (Sutch and Elias 2007, 164).

The notions of national sovereignty and non-interference have now been undermined by the notion of universal human rights. In the words of Andrew Hurrell, "[s]overeignty in the sense of power of the state over its national has been eroded by human rights law and by the increases availability to groups and individuals of a range of national courts and 
international tribunals" (Hurrell 2007, 149). It is now acceptable for countries to make a response to gross human rights violation of other countries. This obviously challenges realists who pay less attention to human rights in international politics.

The next issue of global humanism discussed here is environmental issues. The issues of environment have been attracting the attention of international communities since the late $1960 \mathrm{~s}$ as a result of industrialization and the exploitation of the resources (Greene 2001, 387-388; Heywood 2011, 384). According to Owen Greene, "[e]nvironmental issues first emerged as a focus for international politics in the nineteenth century in the context of international agreements to manage resources" (Greene 2005, 453). However, a more serious attention to environmental issues has just been devoted by global communities in the late twentieth century, as a result of the inevitable global impacts of environment (Greene 2005, 452). In this regard, global institutions have an important role in tackling the environmental issues. The environmental issue cannot be left to states alone since states tend to consider their national interest rather than global interest. Global environmental issues are dealing with international security. Elizabeth R. DeSombre argues that global environmental issues "have changed the way we think about what constitutes security" (DeSombre 2002, 31). Global communities have recently recognized that global envi-ronmental issues are dealing with international security since most environmental issues crossing the borders and impinging on other states (DeSombre 2002, 31). Unless global com-munities are able to cope with global environmental issues, they probably will become a new type of global conflicts, especially if it deals with the scarcity of resources. The efforts by global communities to tackle global environmental issues are intended to avoid global conflict.

Global environmental issues have challenged the notion of nation-state sovereignty and nation-states which is viewed as the only actors in international politics by realists. In order to cope with global environmental problems, nation-states need to cooperate with global communities. In doing so, they have to compromise their national interests for the sake of global interests. It is true that nation-states remain primary actors in responding to global environmental issues in terms of legislating and implementing environmental regulations. But they need to have a global cooperation to cope with and share the roles with non-state actors such as supranational organizations (e.g. the European Union), international organizations, transnational corporations, international financial institutions, NGOs, social movements, women groups, consumer groups, and scientists (Greene 2005, 458). 
One of the major environmental issues today is global warming. Global warming has changed the way global communities look at environmental issues. It is now thought that environmental issues are transnational issues crossing state boundaries. No country is immune from the negative impacts of global warming. No country is able to tackle global environmental issues alone. Therefore it requires a global cooperation. A number of international environmental meetings, agreements and programmes were held and established during the second half of the twentieth century and the early twenty-first century. For example, the 1972 UN Conference on the Human Environment was held in Stockholm with the aim "to establish an international framework to promote a more coordinated approach to pollution and other environmental problems" (Greene 2005, 454). The conference is seen as "a turning point in the development of international environmental politics" (Greene 2005, 454).

The explanations above demonstrate that environmental issues are central to international relations today. Unlike realists who excluded these issues, global humanists admits the importance of environmental issues for the survivability of human beings and the planet. Overall, the ecological blindness of international relations is out of date at the present time (Eckersley 2007).

\section{Conclusion}

This article has discussed foreign policy and national interest in international relations. It shows that the view of realism is still valid in particular regarding the role of states in international relations. Although its role is undermined by international organizations and nonstate actors such as transnational corporations and NGOs, states remain play an important role. However, the way realists look at the nature of foreign policy and national interest is debatable and therefore it is difficult to claim that realism is the best approach.

This article shows the weaknesses of realist arguments regarding foreign policy and national interest by referring to liberalism and global humanism. By focusing on the issues of economic globalization, democracy, human rights, and environment, this article argues that foreign policy and national interest is not always in conflict and no longer exclusively related to the interest of state. In fact, cooperation among states is an inherent part of international relations. Global communities admit that the global interest reflecting the interest of human beings. 
However, it does not mean that liberalism and global humanism are the best approaches or provides remedies for global problems. It is an exaggeration to argue that the world is now a better place in relation to the four issues discussed here. In fact, these issues are still problema-tic. Economic globalization generates socio-economic gap between the rich and the poor countries (Stiglitz 2002). In some cases, new democracies are accompanied by the resurgence of ethnic nationalism leading to horizontal conflict or even civil war (Mansfield and Snyder 2005). Human rights are still being violated in many parts of the world (Robertson QC 2006). Interna-tional agreements to tackle environmental issues tend to be limited to environmental protection and pollution, without linking to global political economy concerns (Greene 2005, 456). Never-theless, liberalism and global humanism are useful approaches to criticize realism.

\section{References List}

\section{Books}

Baehr, Peter R., and Monique Castermans-Holleman, 2004. The Role of Human Rights in Foreign Policy. Third Edition. New York: Palgrave Macmillan.

Burchill, Scott, 2005. The National Interest in International Relations Theory. New York: Pal-grave Macmillan.

DeSombre, Elizabeth R., 2002. The Global Environment and World Politics. London: Conti-nuum.

Doods, Klaus., 2000. Geopolitcs in a Changing World. Harlow, England: Prentice Hall.

Dunne, Tim and Brian C. Schmidt, 2001. 'Realism', in John Baylis and Steve Smith (eds.), The Globalization of World Politics: An Introduction to International Relations. Second Edition. Oxford: Oxford University Press.

Dunne, Tim and Brian C. Schmidt, 2005. 'Realism', in John Baylis and Steve Smith (eds.), The Globalization of World Politics: An Introduction to International Relations. Third Edition. Oxford: Oxford University Press.

Eckersley, Robyn, 2007. 'Green Theory', in Dunne, Tim, Kurki, Milja and Smith, Steve. Interna-tional Relations Theories: Discipline and Diversity. Oxford: Oxford University Press.

Forsythe, David P., 2006. Human Rights in International Relations. Second Edition. Cambridge: Cambridge University Press.

Goldstein, Joshua S. and Jon C. Pevehouse, 2008. International Relations. Brief Fourth Editi-on, New York: Pearson Longman.

Gowa, Joanne, 1999. Ballots and Bullets: The Elusive Democratic Peace. Princeton, New Jersey: Princeton University Press. 
Greene, Owen, 2001. 'Environmental Issues', in John Baylis and Steve Smith (eds.). The Globalization of World Politics: An Introduction to International Relations. Second Editi-on. Oxford: Oxford University Press.

Greene, Owen, 2005. 'Environmental Issues', in John Baylis and Steve Smith (eds.). The Global-ization of World Politics: An Introduction to International Relations. Third Edition. Oxford: Oxford University Press.

Gurtov, Mel, 2007. Global Politics in the Human Interest. Fifth Edition. Boulder: Lynne Rien-ner Publishers.

Heywood, Andrew, 2011. Global Politics. New York: Palgrave Macmillan. Hocking, Brian and Michael Smith, 1995. World Politics: An Introduction to International Relations. Second Edition. London: Prentice Hall/Harvester Wheatsheaf.

Hurrell, Andrew, 2007. On Global Order: Power, Values, and the Constitution of International Society. Oxford: Oxford University Press.

Jackson, Robert and Georg Sørensen, 2003. Introduction to International Relations: Theories and Approaches. Second Edition. Oxford: Oxford University Press.

Mansbach, Richard W. and Kirsten L. Rafferty, 2008. Introduction to Global Politics. London and New York: Routledge.

Mansfield, Edward D. and Jack Snyder, 2005. Electing to Fight: Why Emerging Democracies go to War. Cambridge, Massachusets: MIT Press.

Morgenthau, Hans J., 2006. Politics Among Nations: The Struggle for Power and Peace. Se-venth Edition. Boston: McGraw-Hill.

Robertson QC, Geoffrey. 2006. Crimes Against Humanity: The Struggle for Global Justice. Third Edition. Victoria: Penguin Books.

Russett, Bruce, 1993. Grasping the Democratic Peace: Principles for a Post-Cold War World. Princeton, New Jersey: Princeton University Press.

Scholte, Jan Aart, 2001, "Global Trade and Finance", in John Baylis and Steve Smith (eds.), The Globalization of World Politics: An Introduction to International Relations. Second Edition. Oxford: Oxford University Press.

Steger, Manfred B., 2003, Globalization: A Very Short Introduction. Oxford: Oxford University Press.

Stiglitz, Joseph E., 2002, Globalization and its Discontents. New York: W. W. Norton.

Sutch, Peter and Juanita Elias, 2007. International Relations: The Basics. Oxon, Routledge.

Waltz, Kenneth N., 1979. Theory of International Politics. Boston: McGraw-Hill.

Webber, Mark, and Michael Smith, 2002. Foreign Policy in a Transformed World. Essex: Pearson Education Limited. 


\section{Journals}

Chan, Steve. 1997. In Search of Democratic Peace: Problems and Promise", Mershon International Studies Review May 41 (1): 59-91.

Rosato, Sebastian. 2003. "The Flawed Logic of Democratic Peace Theory", American Political Science Review, November 97 (4): 585602.

Yeung, Henry Wai-chung, 2002. "The Limits to Globalization Theory: A Geographic Perspective on Global Economy Change", July Economic Geography 78 (3): 285-305. 